\title{
HUBUNGAN KARAKTERISTIK IBU DENGAN SECTIO CAESAREA DI RUMAH SAKIT TK IV 01.07.001 KESDAM I/BB PEMATANGSIANTAR
}

\author{
Dodoh Khodijah, Yessika Rouli Siburian, Renny Sinaga \\ Prodi Kebidanan Kemenkes Pematangsiantar
}

\begin{abstract}
Abstrak
Latar belakang :Sekalipun terdapat kesan tindakan operasi persalinan makin liberal tetapi bukan tanpa alasan medis atau indikasi yang tepat. Data yang diperoleh di Rumah Sakit Tk IV 01.07.001 Kesdam I/BB Pematangsiantar bahwa kejadian Sectio Caesarea meningkat mulai tahun 2011-2012 sebesar $2 \%$. Tujuan penelitian ini akan menghubungkan faktor karakteristik ibu dengan Sectio Caesarea di Rumah Sakit Tk IV 01.07.001 Kesdam I/BB Pematangsiantar. Metode penelitian ini bersifat analitik menggunakan data Sekunder. Populasi penelitian adalah seluruh ibu bersalin di Rumah Sakit Tk IV 01.07.001 Kesdam I/BB Pematangsiantar tahun 2013 sebanyak 535 orang. Pengambilan sample menggunakan rumus Slovin dengan sistem Random Sampling berjumlah 230 orang. Kemudian dibuat tabulasi frekuensi dan tabulasi silang dengan taraf signifikan $\alpha=0,05$. Hasil penelitian tentang hubungan karakteristik Ibu dengan Sectio Caesarea terdapat hubungan faktor Umur dan Indikasi dengan kejadian persalinan SC. Tingginya angka kejadian SC perlu dilakukan penyuluhan tentang pentingnya kesehatan reproduksi dalam kehamilan dan deteksi dini untuk mengatasi terjadinya komplikasi sehingga perlu adanya pemeriksaan kehamilan secara teratur.
\end{abstract}

Kata kunci : Umur, Paritas, Jarak Kehamilan, Pendidikan, Pekerjaan, indikasi Sectio Caesarea

\section{PENDAHULUAN}

\section{Latar Belakang}

Kesehatan Ibu dan Anak menjadi target dalam Tujuan Pembangunan Millenium (MDGs), tepatnya pada tujuan 4 dan 5 yaitu menurunkan Angka Kematian Anak dan Meningkatkan Kesehatan Ibu. Program Kesehatan Ibu dan Anak (KIA) menjadi sangat penting karena merupakan unsur penting pembangunan, hal ini mengandung pengertian bahwa dari seorang Ibu akan dilahirkan caloncalon penerus bangsa yaitu anak, yang dapat memberikan manfaat bagi bangsa, maka harus diupayakan kondisi ibu dan anak yang sehat (Prasetyawati, 2012).

Bidan sebagai tenaga terlatih, berperanan penting dalam mata rantai "sistem kesehatan nasional" sehingga masyarakat mendapat pelayanan dan pengayoman medis lebih menyeluruh dan lebih bermutu. Perkiraan di Indonesia, jumlah persalinan sebanyak 5.000.000 per tahun, maka jumlah kematian ibu sebanyak 20.000 sampai 22.000 orang sedangkan angka kematian perinatal 28.000 sampai 30.000 orang setiap tahun. Kematian Ibu dan perinatal ini tertinggi di negara ASEAN (Manuaba, 2010).

Berdasarkan hasil Survei Demografi dan Kesehatan Indonesia (SDKI) 2012, angka kematian ibu mencapai 359 per 100 ribu kelahiran hidup. Dalam survei yang sama lima tahun lalu, angka kematian ibu hanya 228 per 100 ribu kelahiran hidup (Tempo, 2012).

Menurut WHO (World Health Organization), standar operasi SC di sebuah negara adalah 5-15 persen. Di Indonesia sendiri, presentase SC sekitar 5 persen. Di rumah sakit pemerintah rata-rata 11 persen, sementara di Rumah
Sakit Swasta rata - rata 30 persen, angka ini terus berkembang (Aini, 2009).

Berbagai survei menemukan bahwa presentasi persalinan SC pada rumah sakit-rumah sakit dikota besar seperti Jakarta dan Bali berada jauh diatas angka tersebut. Secara umum, jumlah persalinan SC di rumah sakit pemerintah adalah sekitar 30-35 \% dari total persalinan sedangkan di rumah sakit swasta jumlahnya sangat tinggi yaitu sekitar 30-80\% dari total persalinan (Rasyid, 2009).

Sekalipun terdapat kesan tindakan operasi persalinan makin liberal tetapi bukan tanpa alasan medis atau indikasi yang tepat. Indikasi pada Ibu, indikasi profilaksis seperti ibu dengan penyakit jantung, paru, ginjal, tekanan darah tinggi, atau pre-eklampsi/eklampsi. Indikasi vital seperti, rupture uteri, kehamilan dengan perdarahan, panggul sempit, kelainan letak janin, persalinan lama. Indikasi pada janin seperti gawat janin, kematian janin dalam kandungan, tali pusat menumbung, walaupun jarang tetapi fatal adalah komplikasi emboli air ketuban yang dapat terjadi selama tindakan operasi (Manuaba, 2010).

Sebuah penelitian menyatakan bahwa terdapat hubungan antara umur ibu, paritas dan komplikasi obstetrik terhadap tindakan SC. Sedangkan faktor resiko terbesar tindakan SC adalah usia ibu yang terlalu muda atau terlalu tua. Selain itu, terdapat hubungan antara riwayat SC terhadap tindakan SC berikutnya (Sinaga, 2007).

Berdasarkan hasil penelitian di Rumah Sakit Umum Daerah Dr.Pringadi Medan pada tahun 2012 diketahui jumlah ibu bersalin dengan $S C$ pada tahun 2011 yaitu sekitar 58,1\% dan tahun 2012 sekitar 60,1\% (Siti, 2013). Survei pendahuluan di Rumah Sakit Tk IV 01.07.01 
Kesdam 1/BB Pematangiantar tahun 2012 ditemukan dari 696 persalinan terdapat 512 orang yang bersalin dengan SC atau sekitar 73,6\%.

Berdasarkan latar belakang di atas penulis tertarik untuk mengadakan penelitian dengan judul : "Hubungan Karakteristik Ibu dengan Sectio Caesarea di Rumah Sakit Tk IV 01.07.01 Kesdam 1/BB Pematangsiantar".

\section{Rumusan Masalah}

Berdasarkan latar belakang di atas, maka rumusan masalah dalam penelitian ini yaitu : "Hubungan Karakteristik Ibu dengan Sectio Caesarea di Rumah Sakit TK IV.01.07.01 Kesdam I/BB Pematangsiantar”.

\section{Tujuan Penelitian}

a. Untuk mengetahui prevalen SC di Rumah Sakit Tk IV.01.07.01 Kesdam I/BB Pematangsiantar.

b. Untuk mengetahui prevalen SC berdasarkan karakteristik umur, paritas, jarak kehamilan, pendidikan, pekerjaan, dan faktor indikasi SC di Rumah Sakit Tk IV.01.07.01 Kesdam I/BB Pematangsiantar.

c. Untuk mengetahui hubungan karakteristik ibu dengan Sectio Caesarea di Rumah Sakit Tk IV.01.07.01 Kesdam I/BB Pematangsiantar.

\section{MANFAAT PENELITIAN}

\section{Manfaat Teoritis}

Sebagai sarana informasi tentang hubungan karakteristik ibu dengan Sectio Caesarea, sehingga dapat dijadikan langkah awal dalam membuat kebijakan pelayanan kebidanan.

\section{Manfaat Praktis}

Sebagai masukan dan informasi bagi petugas kesehatan terutama para bidan untuk mendeteksi dini terjadinya komplikasi kehamilan dan persalinan serta mencegah terjadinya peningkatan persalinan dengan SC.

\section{METODOLOGI PENELITIAN}

\section{Desain Penelitian}

Jenis Penelitian ini adalah penelitian observasional dengan desain crossectional dengan menggunakan data sekunder untuk mengetahui hubungan karakteristik ibu dengan Sectio Caesarea di Rumah Sakit Tk IV 01.07.001 Kesdam I/BB Pematangsiantar.

\section{Populasi}

Populasi dalam penelitian ini semua ibu yang bersalin di Rumah Sakit Tk IV 01.07.001 Kesdam I/BB Pematangsiantar pada tahun 2013 yaitu sebanyak 535 orang

\section{Sampel}

Besar sampel dihitung dengan menggunakan Rumus Slovin :

$$
\begin{aligned}
\mathrm{n} & =\frac{\mathrm{N}}{1+\mathrm{N}(\mathrm{d})^{2}} \\
& =\frac{535}{1+535(0,05)^{2}}=\frac{535}{1+535(0,0025)} \\
& =\frac{535}{1+1,33} \quad=\frac{535}{2,33} \\
& =229,6 \\
& =230
\end{aligned}
$$

Sampel diambil dengan teknik Random Sampling. Data penelitian ini menggunakan data sekunder yang diperoleh dari rekam medik di Rumah Sakit TK.IV.01.07.01 Kesdam I/BB Pematangsiantar pada tahun 2013 dengan menggunakan lembar checklist.

\section{ANALISA DATA}

Analisa data penelitian ini dengan bantuan software Stata versi 16. Dilakukan analisis univariabel, analisis bivariabel dengan menggunkan Chi square $\left(\mathrm{X}^{2}\right)$ pada tingkat kemaknaan $\mathrm{p}<0,05$ dengan Confidence Interval (CI) 95 persen.

\section{HASIL PENELITIAN}

Analisa Univariabel

Tabel 1. Distribusi Ibu bersalin di Rumah Sakit Tk IV.01.07.001 Kesdam I/BB Pematangsiantar

Data : Rekam Medik 2013

\begin{tabular}{clccc}
\hline No & & Kategori & F & $(\%)$ \\
\hline 1 & SC & & 215 & 93,5 \\
2 & Tidak SC & 15 & 6,5 \\
\hline & Jumlah & $\mathbf{2 3 0}$ & $\mathbf{1 0 0 \%}$ \\
\hline
\end{tabular}

Tabel 2. Distribusi ibu bersalin berdasarkan Karakteristik di Rumah Sakit Tk IV.01.07.001 Kesdam I/BB Pematangsiantar

\begin{tabular}{clccc}
\hline No & & Karakteristik & F & $(\boldsymbol{\%})$ \\
\hline & Umur & & 5,7 \\
\hline 1 & $<20$ tahun & 13 & 80 \\
2 & $20-35$ tahun & 184 & 14,3 \\
3 & $>35$ tahun & 33 & $100 \%$ \\
\hline & Jumlah & 230 & \\
\hline & & Paritas & & \\
\hline
\end{tabular}




\begin{tabular}{|c|c|c|c|}
\hline 1 & Primi gravida & 68 & 29,6 \\
\hline 2 & Multi gravida & 140 & 60,9 \\
\hline \multirow[t]{3}{*}{3} & Grande multi gravida & 22 & 9,6 \\
\hline & Jumlah & 230 & $100 \%$ \\
\hline & \multicolumn{3}{|l|}{ Jarak Kehamilan } \\
\hline 1 & $<2$ tahun & 78 & 33,9 \\
\hline 2 & 2-3 tahun & 81 & 35,2 \\
\hline \multirow[t]{3}{*}{3} & $>3$ tahun & 71 & 30,9 \\
\hline & Jumlah & 230 & $100 \%$ \\
\hline & \multicolumn{3}{|l|}{ Pendidikan } \\
\hline 1 & SD & 24 & 10,4 \\
\hline 2 & SMP & 52 & 22,6 \\
\hline 3 & SMA & 105 & 45,7 \\
\hline \multirow[t]{3}{*}{4} & PT & 49 & 21,3 \\
\hline & Jumlah & 230 & $100 \%$ \\
\hline & \multicolumn{3}{|l|}{ Pekerjaan } \\
\hline 1 & IRT & 49 & 21,4 \\
\hline 2 & Petani & 50 & 21,7 \\
\hline 3 & Wiraswasta & 102 & 44,3 \\
\hline \multirow[t]{3}{*}{4} & PNS & 29 & 12,6 \\
\hline & Jumlah & 230 & $100 \%$ \\
\hline & \multicolumn{3}{|l|}{ Indikasi } \\
\hline 1 & CPD & 30 & 13,0 \\
\hline 2 & Riwayat SC & 39 & 17,0 \\
\hline 3 & PE & 14 & 6,1 \\
\hline 4 & Plasenta Previa & 16 & 7,0 \\
\hline 5 & Solusio Plasenta & 11 & 4,8 \\
\hline 6 & PTM & 35 & 15,2 \\
\hline 7 & KPD & 21 & 9,1 \\
\hline 8 & Gawat Janin & 13 & 5,7 \\
\hline 9 & Malpresentasi & 17 & 7,4 \\
\hline \multirow[t]{2}{*}{10} & Permintaan SC & 34 & 14,8 \\
\hline & Jumlah & 230 & 100 \\
\hline
\end{tabular}

Data : Rekam Medik 2013

Tabel 3. Tabel Kontingensi Karakteristik Ibu bersalin dengan Sectio Caesarea di Rumah Sakit Tk IV.01.07.001 Kesdam I/BB Pematangsiantar

\begin{tabular}{|c|c|c|c|c|c|c|c|c|c|}
\hline \multicolumn{2}{|r|}{ Karakteristik } & \multicolumn{4}{|c|}{ SC } & \multirow{2}{*}{\multicolumn{2}{|c|}{ Total }} & \multirow{3}{*}{$\mathbf{x}^{2}$} & \multirow{3}{*}{$\mathbf{P}$} \\
\hline & \multirow[b]{2}{*}{ Umur } & \multicolumn{2}{|c|}{ Ya } & \multicolumn{2}{|c|}{ Tidak } & & & & \\
\hline & & $\mathbf{F}$ & $\%$ & $\mathbf{F}$ & $\%$ & f & $\%$ & & \\
\hline 1 & $<20$ tahun & 10 & 76,9 & 3 & 23,1 & 13 & 100 & & \\
\hline 2 & 20-35 tahun & 176 & 95,7 & 8 & 4,3 & 184 & 100 & & \\
\hline \multirow[t]{2}{*}{3} & $>35$ tahun & 29 & 12,6 & 4 & 1,7 & 33 & 14,3 & 8,96 & 0,01 \\
\hline & Paritas & & & & & & & & \\
\hline 1 & Primi gravida & 65 & 95,6 & 3 & 4,4 & 68 & 100 & & \\
\hline 2 & Sekundi gravida & 73 & 94,8 & 4 & 5,2 & 77 & 100 & & \\
\hline 3 & Multi gravida & 58 & 92,0 & 5 & 8,0 & 63 & 100 & 2,75 & 0,43 \\
\hline \multirow[t]{2}{*}{4} & Grandemulti gravida & 19 & 86,3 & 3 & 13,7 & 22 & 100 & & \\
\hline & Jarak Kehamilan & & & & & & & & \\
\hline 1 & $<2$ tahun & 75 & 96,1 & 3 & 3,9 & 78 & 100 & & \\
\hline 2 & 2-3 tahun & 74 & 91,3 & 7 & 8,7 & 81 & 100 & 1,54 & 0,46 \\
\hline \multirow[t]{2}{*}{3} & $>3$ tahun & 66 & 93,0 & 5 & 7,0 & 71 & 100 & & \\
\hline & Pendidikan & & & & & & & & \\
\hline 1 & SD & 22 & 91,6 & 2 & 8,4 & 24 & 100 & & \\
\hline 2 & SMP & 50 & 96,1 & 2 & 3,9 & 52 & 100 & 1,94 & 0,585 \\
\hline 3 & SMA & 99 & 94,2 & 6 & 5,8 & 105 & 100 & & \\
\hline \multirow[t]{2}{*}{4} & PT & 44 & 89,7 & 5 & 10,2 & 49 & 100 & & \\
\hline & Peker & & & & & & & & \\
\hline 1 & IRT & 46 & 93,8 & 3 & 6,2 & 49 & 100 & & \\
\hline
\end{tabular}




\begin{tabular}{llcccccccc}
2 & Petani & 45 & 90 & 5 & 10 & 50 & 100 & 1,523 & 0,677 \\
3 & Wiraswasta & 96 & 94,1 & 6 & 5,9 & 102 & 100 & & \\
4 & PNS & 28 & 96,5 & 1 & 3,5 & 29 & 100 & & \\
\hline Indikasi & 28 & 93,3 & 2 & 6,6 & 30 & 100 & & \\
\hline 1 & CPD & 39 & 100 & 0 & 0 & 39 & 100 & & \\
2 & Riwayat SC & 10 & 71,4 & 4 & 28,6 & 14 & 100 & & \\
3 & PE & 16 & 100 & 0 & 0 & 16 & 100 & 230,00 & 0,00 \\
4 & Plasenta Previa & 11 & 100 & 0 & 0 & 0 & 100 & & \\
5 & Solusio Plasenta & 32 & 91,5 & 3 & 8,5 & 35 & 100 & & \\
6 & PTM & 20 & 95,2 & 1 & 4,8 & 21 & 100 & & \\
7 & KPD & 13 & 100 & 0 & 0 & 13 & 100 & & \\
8 & Gawat Janin & 12 & 70,6 & 5 & 29,4 & 17 & 100 & & \\
9 & Malpresentasi & 34 & 100 & 0 & 0 & 34 & 100 & & \\
10 & Permintaan SC & 230 & 7 & 15 & 70 & & & \\
\hline & Jumlah & & 7000 & & & & \\
\hline
\end{tabular}

Data : Rekam Medik 2013

Analisa data :

Berdasarkan tabel di atas, dapat diketahui bahwa $(95,7 \%)$ ibu bersalin berusia $20-35$ tahun bersalin dengan SC. Hasil analisis menunjukkan terdapat hubungan antara umur dengan kejadian SC dengan nilai $P=0,01$. Berdasarkan Indikasi SC bahwa ibu yang mempunyai riwayat SC $100 \%$ bersalin dengan SC juga. Analisis menunjukkan ada hubungan riwayat SC dengan kejadian $\operatorname{SC}(P=<0,01)$.

\section{PEMBAHASAN}

\section{a. Distribusi ibu terhadap Sectio Caesarea}

Data rekam medik persalinan di Rumah Sakit Tk IV 01.07.001 Kesdam I/BB Pematangsiantar pada bulan Januari - Desember 2013 menunjukkan dari 535 persalinan didapatkan 497 kasus persalinan Sectio Caesarea $(92,9 \%)$ dan 38 persalinan normal $(7,1 \%)$. Penelitian yang sama diungkapkan oleh Aulia (2011) di RSUD Dr. Adjidarmo tahun 2010 kasus persalinan Sectio Caesarea $(63,4 \%)$. Namun, hasil penelitian ini tidak sesuai dengan penelitian Sadiman (dalam Silvia Aulia 2011) dan M Ridwan di RSUD A. Yani Metro (2008) yang memproleh persalinan Sectio Caesarea lebih kecil angka kejadiannya (29,7\%). Hal ini terjadi karena Rumah Sakit Tk IV 01.07.001 Kesdam I/BB Pematangsiantar merupakan salah satu Rumah sakit rujukan milik pemerintah. Mayoritas semua golongan ekonomi masyarakat menjadikan Rumah sakit ini sebagai pusat rujukan dengan alasan selain biaya yang masih terjangkau juga pelayanannya masih tergolong baik.

Sebagian besar persalinan yang dibawa ke Rumah Sakit Tk IV 01.07.001 Kesdam I/BB Pematangsiantar adalah kasus rujukan dengan persalinan penyulit dari fasilitas kesehatan lain, sehingga harus segera mendapat pertolongan, terutama melalui persalinan Sectio Caesarea. Fakta ini menguatkan bahwa kasus persalinan di Rumah Sakit ini hampir keseluruhan dilakukan tindakan SC. Saat ini SC menjadi trend di masyarakat. Persalinan SC banyak dilakukan atas permintaan pasien itu sendiri, hal ini menyebabkan peningkatan angka kejadian persalinan
SC. Kenyataan tersebut turut menguatkan alasan mengapa persalinan SC dalam penelitian ini lebih banyak dari persalinan normal.

\section{b. Distribusi Karakteristik Ibu 1. Umur}

Umur mempengaruhi kejadian SC. Pada penelitian ini mayoritas berusia 20-35 tahun sebanyak 184 ibu (80\%). Menurut Saifuddin 2009 (dalam Trivoni, 2012) dikatakan bahwa usia 20-35 tahun merupakan usia reproduksi wanita, dimana diusia tersebut seorang ibu mampu hamil dalam kondisi yang sehat baik fisik maupun psikologis. Pada ibu hamil usia ini dianggap ideal untuk menjalani kehamilan dan proses persalinan. Kemampuan rahim untuk mempertahankan kehamilan sangat ditentukan oleh usia ibu. Meningkatnya usia ibu juga membuat kondisi dan fungsi rahim menurun dan salah satu akibatnya adalah jaringan rahim yang tidak subur lagi. Jaringan rongga panggul dan otot-ototnya pun melemah sejalan dengan bertambahnya usia. Hal ini membuat rongga panggul tidak mudah lagi menghadapi dan mengatasi komplikasi berat.

Hal ini senada dengan penelitian Ezra Marisi, 2007 (dalam Aulia, 2011) di RSUD Sidikalang yang menyatakan $(78,7 \%)$ adalah ibu melahirkan dengan umur 20-35 tahun. Komplikasi yang mungkin timbul saat kehamilan juga dapat mempengaruhi jalannya persalinan sehingga SC dapat dianggap sebagai cara terbaik untuk melahirkan janin. Penelitian Nurhasannah 2010 (dalam Trivonia, 2012) pada tahun 2010 di RSU Bhakti Yudha Depok didapatkan sebanyak 78\% kasus terjadi pada usia 20-35 tahun. Hal ini disebabkan oleh perkembangan indikasi baik dari indikasi medis yaitu faktor ibu dan janin maupun indikasi sosial.

Selain itu, hal ini juga dikarenakan jumlah ibu hamil yang melahirkan di usia $>35$ dan $<20$ tahun memiliki jumlah yang jauh lebih sedikit dibandingkan dengan ibu yang melahirkan di usia kelompok 20-35 tahun.

Sedangkan berdasarkan analisis bivariat dalam penelitian ini dapat dinyatakan bahwa terdapat hubungan antara umur ibu dengan kejadian SC. Ibu yang berumur 
dibawah 20 tahun atau diatas 35 tahun sangat berisiko untuk persalinan patologis sebagai indikasi SC. Kehamilan ibu dengan usia dibawah 20 tahun berpengaruh pada kematangan fisik dan mental dalam menghadapi kehamilan dan persalinan. Rahim dan panggul ibu sering kali belum tumbuh matang mencapai ukuran dewasa. Selain itu mental ibu juga berpengaruh terhadap pada ketrampilan ibu dalam merawat diri ibu dan bayinya. Sehingga pada usia ini ibu cenderung mengalami persalinan SC walaupun tanpa indikasi dengan pertimbangan kekhawatiran ibu pada dirinya dalam menghadapi proses persalinan dan keselamatan janin dalam kandungannya (Hutabalian, 2011).

\section{Paritas}

Hasil penelitian ini menunjukkan mayoritas merupakan Sekundi gravida sebanyak 77 ibu (33,5\%) dan minoritas pada ibu Grandemulti gravida sebanyak 22 ibu (9,6\%). Menurut Saifuddin, 2009 (dalam Trivonia, 2012), paritas yang paling aman adalah multi gravida. Primi gravida dan Grande multi gravida mempunyai angka kematian maternal lebih tinggi. Hal ini dipengaruhi oleh kematangan dan penurunan fungsi organ-organ persalinan.

Secara umum paritas multi gravida merupakan paritas paling aman bagi seorang ibu untuk melahirkan dan masih digolongkan dalam kehamilan resiko rendah. Meskipun demikian tetap ada faktor resiko yang menyebabkan kemungkinan resiko atau bahaya terjadinya komplikasi pada persalinan yang dapat menyebabkan kematian atau kesakitan pada ibu dan bayinya. Misalnya pada ibu multi gravida yang pernah gagal kehamilan, pernah melahirkan dengan vakum, transfusi darah atau uri dirogoh, serta riwayat bedah sesar pada persalinan sebelumnya (Trivonia, dkk, 2011).

Persalinan yang pertama sekali biasanya mempunyai resiko yang relatif tinggi terhadap ibu dan anak, akan tetapi resiko ini akan menurun pada paritas kedua dan ketiga, dan akan meningkat lagi pada paritas keempat dan seterusnya. Paritas yang paling aman jika ditinjau dari sudut kematian maternal adalah paritas 2 dan 3 (Prawirohardjo, 2011). Hasil analisis bivariabel menunjukkan tidak ada hubungan paritas dengan kejadian SC. Pendapat yang sama diungkapkan oleh Yuli K, (2006) di Rs Dr. Moewardi Surakarta.

\section{Jarak Kehamilan}

Seorang wanita setelah melahirkan membutuhkan 2 sampai 3 tahun untuk memulihkan tubuhnya dan mempersiapkan dirinya pada persalinan berikutnya dan memberi kesempatan pada luka untuk sembuh dengan baik. Jarak persalinan yang pendek akan meningkatkan resiko terhadap ibu dan anak (Marisi, 2009).

Hasil penelitian ini mayoritas pada persalinan SC berjarak kehamilan $<2$ tahun sebanyak 75 ibu $(32,6 \%)$ dari 215 ibu. Pada penelitian ini menunjukkan tidak ada hubungan jarak kehamilan dengan tindakan persalinan SC. Hal ini sesuai dengan penelitian Anita V tahun 2007 di Rumah Sakit Vita Insani Pematangsiantar bahwa proporsi ibu yang mengalami persalinan dengan SC tertinggi 43,4\% dengan jarak persalinan 0. Dalam penelitian tersebut juga mengungkapkan tidak ada hubungan antara jarak kehamilan dengan kejadian persalinan SC,

4. Pendidikan

Hasil penelitian yang dilakukan di di Rumah Sakit Tk IV 01.07.001 Kesdam I/BB Pematangsiantar pada bulan Januari - Desember 2013 menunjukkan dari $230 \mathrm{ibu}$ bersalin, mayoritas berada pada jenjang pendidikan SMA yaitu sebanyak $105 \mathrm{ibu}(45,7 \%)$ dan minoritas pada jenjang pendidikan SD sebanyak 24 Ibu (10,4\%).

Pendidikan berasal dari kata didik. Menurut KBBI (2003) didik adalah memberikan pengetahuan, ini berarti makin tinggi pendidikan seseorang maka makin tinggi pula pengetahuan yang dimilikinya. Pernyataan ini sesuai dengan teori dari Notoadmodjo (2003) mengatakan bahwa semakin tinggi pendidikan seseorang, makan semakin luas pengetahuan tentang suatu hal dan semakin luas pula wawasan berfikirnya. Ibu yang memiliki tingkat pengetahuan tinggi cenderung lebih memperhatikan kesehatan, dan juga kehamilannya. Ibu juga cenderung mencari informasi sebanyak-banyaknya terkait kehamilan dan persalinan. Namun pada zaman sekarang ini, kebanyakan justru ibu yang berpendidikan tinggi yang meminta persalinan dengan SC (Jovany, 2012). Hasil analisis bivariabel menunjukkan tidak ada hubungan secara statistik.

\section{Pekerjaan}

Hasil penelitian ini menemukan mayoritas responden bekerja sebagai Wiraswasta $(44,3 \%)$ paling rendah pada PNS (12,2). SC merupakan jenis persalinan dimana ibu dapat menentukan tanggal dan waktu persalinan. Dengan dilakukan SC, ibu yang bekerja dapat lebih mudah mengatur jadwal kelahiran yang dapat disesuaikan dengan pekerjaan (Jovany, 2012). Pada penelitian ini terlihat tidak terdapat hubungan yang signifikan.

Hasil penelitian ini berbeda dengan hasil penelitian Ginting tahun 2002 di Rumah Sakit Umum Herna bahwa proporsi ibu yang mengalami persalinan dengan SC tertinggi 57,7\% dengan pekerjaan Ibu Rumah Tangga. Namun juga bukan berperan penting dalam faktor penyebab persalinan SC, tetapi karena ada faktor lain yang cukup kuat untuk dilakukannya tindak persalinan SC (Trivonia, dkk 2011).

\section{Indikasi}

Penelitian yang dilakukan di di Rumah Sakit Tk IV 01.07.001 Kesdam I/BB Pematangsiantar pada bulan Januari - Desember 2013 menunjukkan dari 230 ibu bersalin, $215 \mathrm{ibu}(93,5 \%)$ bersalin dengan Sectio Caesarea dan 15 ibu (6,5\%) bersalin dengan Tidak SC (Pervaginam). Dari 215 ibu yang bersalin dengan SC mayoritas atas indikasi Riwayat SC sebanyak 39 ibu (17,0\%) dan minoritas atas indikasi PE sebanyak 10 ibu (4,3\%). Sedangkan pada Ibu yang bersalin dengan tidak SC, mayoritas atas Indikasi Malpresentasi sebanyak 5 ibu $(2,2 \%)$. 
Faktor indikasi dalam penelitian ini yaitu CPD,Riwayat SC, PE, Plasenta Previa, Solusio Plasenta, PTM, KPD, Gawat Janin, Malpresentasi, Permintaan SC. Faktor Permintaan dilakukan karena kemungkinan si ibu takut pada persalinan normal, dan karena mitos-mitos yang berkembang dimasyarakat seputar persalinan normal. Contoh mitos tersebut adalah bahwa persalinan normal akan merusak vagina, dan bayi yang akan dilahirkan dengan SC akan lebih pintar karena kepalanya tidak terjepit jalan lahir (Jovany, 2012).

Hasil analisis bivariat menunjukkan bahwa terdapat hubungan antara faktor Indikasi dengan dilakukannya persalinan SC. Mayoritas oleh indikasi Riwayat SC yaitu sebanyak 39 ibu $(17,0 \%)$ dari 215 ibu yang bersalin dengan SC (93,5\%) dan minoritas oleh indikasi Preeklampsi sebanyak $10 \mathrm{ibu}(4,3 \%)$.

Menurut Kaufmann, 2006 dalam (Jovany, 2012) bahwa terdapat berbagai macam alasan medis untuk dilakukan SC, lebih dari $85 \%$ alasan ini sesuai dengan salah satu diantara empat kelompok umum yaitu riwayat SC sebelumnya $(37,4 \%)$ dari seluruh SC, distosia $(23,3 \%)$, bayi sungsang $(14,7 \%)$, dan gawat janin $(10,3 \%)$. Pernah dilakukan SC sebelumnya merupakan salah satu faktor ibu dilakukan SC berikutnya. Padahal ibu yang baru pertama kali dilakukan SC memiliki kesempatan besar untuk melahirkan secara pervaginam.

Menurut Sudirman, 2009 faktor-faktor medis dilakukan SC adalah karena faktor ibu dan faktor janin. Faktor medis ibu dilakukannya SC adalah plasenta previa $(5,3 \%)$, riwayat persalinan ibu yang lalu mengalami SC $(5,7 \%)$, disproporsi sefalopelvic (3,3\%), Pre-eklampsi Berat (25,6\%), Ketuban Pecah Dini (31,7\%). Faktor medis Janin dilakukan tindakan SC yaitu letak sungsang (11\%), letak lintang $(5,3 \%)$, gawat janin $(7,7 \%)$ dan gemelli $(7,7 \%)$ (Jovany, 2012).

Hasil penelitian ini menyebutkan bahwa ada juga faktor indikasi SC dengan Permintaan pasien itu sendiri, sebanyak 34 ibu (14,8\%). Menurut Andriana 2007 (dalam Jovany 2012) bahwa tidak sedikit pula ibu melahirkan dengan SC karena permintaan ibu yang tidak ingin menjalani persalinan normal karena adanya rasa takut.

\section{KESIMPULAN}

1. Dari 230 ibu bersalin, mayoritas dengan tindakan persalinan Sectio Caesarea sebanyak $215 \mathrm{ibu}(93,5 \%)$.

2. Distribusi variabel karakteristik berdasarkan umur mayoritas berumur 20-35 tahun (80,0\%), multigravida $(60,9 \%)$, Jarak Kehamilan jarak kehamilan 2-3 tahun sebanyak $(35,2 \%)$, pendidikan SMA $(45,7)$, Wiraswasta $(44,3 \%)$ dengan Indikasi SC terbesar (17,0\%).

3. Terdapat hubungan faktor Umur dan indikasi dengan kejadian SC

4. Tidak ada hubungan faktor paritas, jarak kehamilan, pendidikan, pekerjaan dengan SC.

\section{SARAN}

1. Disarankan bagi petugas kesehatan/bidan diharapkan untuk melakukan deteksi dini adanya penyulit selama ANC dan persalinan agar frekuensi ibu bersalin dengan SC berkurang.

2. Melakukan pendidikan kesehatan tentang konsep persalinan normal pada ibu hamil.

\section{DAFTAR PUSTAKA}

Aini, H. 2009. Buku Pintar Menjalani 9 Bulan Kehamilan. Tora Book. Yogyakarta.

Aulia, S. 2011. Faktor-faktor Resiko Persalinan Seksio Sesarea. UINSyah. Jakarta.

Jovany, M. 2012. Faktor-faktor yang Mempengaruhi Keputusan Ibu Dilakukan Seksio Sesarea yang Kedua. FIK UI. Depok.

Kompas,2012.https://www.facebook.com/notes/komunitas -sehat-cantik-langsing/selamatkan-ibu-dari-bahayaoperasicaesar/10151014391551612

Kusumawati, Yuli. Faktor-faktor Risiko yang Berpengaruh Terhadap Persalinan dengan Tindakan. UNDIP. Semarang.

Latin.Y.L. 2014. Instant Access Ilmu Kebidanan. Binarupa Aksara. Jakarta.

Lukas.E.2010.http//med.unhas.ac.id/ obgin/index.php? option=com_content \& task $=$ view\&id=89\&Itemid=1, [diakses tanggal 0503-2014,jam 10:50 Wib]

Manuaba, dkk. 2010. Ilmu Kebidanan, Penyakit Kandungan, dan KB. Buku Kedokteran. Jakarta.

Marisi. 2009. Karakteristik Ibu Yang Mengalami Persalinan Dengan Seksio Sesarea Yang Dirawat Inap di Rumah Sakit Umum Daerah Sidikalang Tahun 2007: USU Repository 2009. Medan.

Oxorn, dkk. 2010. Ilmи Kebidanan: Patologi \& Fisiologi Persalinan. ANDI. Yogyakarta.

Prasetyawati, A, E. 2012. Kesehatan Ibu dan Anak (KIA). Nuha Medika. Yogyakarta.

Prawirohardjo.S. 2011. Ilmu Kebidanan. Bina Pustaka. Jakarta.

Rasyid. 2009. Pengaruh Hipnotherapi Terhadap Tingkat Kecemesan Ibu yang Akan Menjalani Seksio Sesarea. UNSemar. Semarang

Saifuddin.A. 2009. Ilmu Kebidanan. Yayasan Bina Pustaka Sarwono Prawirodihardjo. Jakarta.

Siti,dkk.

2013.

https://www.google.com/\#q=jurnal+persalinan+ses ar+pdf [diakses 03 Maret 2014 pukul 21:14 Wib].

Trivonia, dkk. 2011. Indikasi Persalinan Sektio Caesarea berdasarkan umur dan paritas, librarygriyahusada.com, [diakses 03 Maret 2014 pukul 20:20 Wib]. 